\title{
Mendigite, $\mathrm{Mn}_{2} \mathrm{Mn}_{2} \mathrm{MnCa}\left(\mathrm{Si}_{3} \mathrm{O}_{9}\right)_{2}$, a New Mineral Species of the Bustamite Group from the Eifel Volcanic Region, Germany ${ }^{1}$
}

\author{
N. V. Chukanov ${ }^{a}$, S. M. Aksenov ${ }^{b}$, R. K. Rastsvetaeva ${ }^{b}$, K. V. Van ${ }^{c}$, D. I. Belakovskiy ${ }^{d}$, \\ I. V. Pekov ${ }^{e}$, V. V. Gurzhiy ${ }^{f}$, W. Schüller ${ }^{g}$, and B. Ternes ${ }^{h}$ \\ ${ }^{a}$ Institute of Problems of Chemical Physics, Russian Academy of Sciences, Chernogolovka, Moscow oblast, 142432 Russia \\ ${ }^{b}$ Institute of Crystallography, Russian Academy of Sciences, Leninsky pr. 59, Moscow, 117333 Russia \\ ${ }^{c}$ Institute of Experimental Mineralogy, Russian Academy of Sciences, Chernogolovka, Moscow oblast, 142432 Russia \\ ${ }^{d}$ Fersman Mineralogical Museum, Russian Academy of Sciences, Leninsky pr. 18-2, Moscow, 119071 Russia \\ ${ }^{e}$ Faculty of Geology, Moscow State University, Moscow, 119991 Russia \\ ${ }^{f}$ Faculty of Geology, St. Petersburg State University, Universitskaya nab. 7/9, St Petersburg, 199034 Russia \\ ${ }^{g}$ Im Straussenpesch 22, 53518 Adenau, Germany \\ ${ }^{h}$ Bahnhofstrasse 45, 56727 Mayen, Germany \\ Received December 10, 2014
}

\begin{abstract}
A new mineral, mendigite (IMA no. 2014-007), isostructural with bustamite, has been found in the In den Dellen pumice quarry near Mendig, Laacher Lake area, Eifel Mountains, Rhineland-Palatinate (Rheinland-Pfalz), Germany. Associated minerals are sanidine, nosean, rhodonite, tephroite, magnetite, and a pyrochlore-group mineral. Mendigite occurs as clusters of long-prismatic crystals (up to $0.1 \times 0.2 \times 2.5 \mathrm{~mm}$ in size) in cavities within sanidinite. The color is dark brown with a brown streak. Perfect cleavage is parallel to (001). $D_{\text {calc }}=3.56 \mathrm{~g} / \mathrm{cm}^{3}$. The IR spectrum shows the absence of $\mathrm{H}_{2} \mathrm{O}$ and $\mathrm{OH}$ groups. Mendigite is biaxial $(-), \alpha=1.722$ (calc), $\beta=1.782(5), \gamma=1.796(5), 2 V_{\text {meas }}=50(10)^{\circ}$. The chemical composition (electron microprobe, mean of 4 point analyses, the $\mathrm{Mn}^{2+} / \mathrm{Mn}^{3+}$ ratio determined from structural data and charge-balance constraints) is as follows (wt \%): $0.36 \mathrm{MgO}, 10.78 \mathrm{CaO}, 37.47 \mathrm{MnO}, 2.91 \mathrm{Mn}_{2} \mathrm{O}_{3}, 4.42 \mathrm{Fe}_{2} \mathrm{O}_{3}$, $1.08 \mathrm{Al}_{2} \mathrm{O}_{3}, 43.80 \quad \mathrm{SiO}_{2}$, total 100.82. The empirical formula is $\mathrm{Mn}_{2.00}\left(\mathrm{Mn}_{1.33} \mathrm{Ca}_{0.67}\right)$ $\left(\mathrm{Mn}_{0.50}^{2+} \mathrm{Mn}_{0.28}^{3+} \mathrm{Fe}_{0.15}^{3+} \mathrm{Mg}_{0.07}\right)\left(\mathrm{Ca}_{0.80} \mathrm{Mn}_{0.20}^{2+}\right)\left(\mathrm{Si}_{5.57} \mathrm{Fe}_{0.27}^{3+} \mathrm{Al}_{0.16} \mathrm{O}_{18}\right)$. The idealized formula is $\mathrm{Mn}_{2} \mathrm{Mn}_{2} \mathrm{MnCa}\left(\mathrm{Si}_{3} \mathrm{O}_{9}\right)_{2}$. The crystal structure has been refined for a single crystal. Mendigite is triclinic, space group $P \overline{1}$; the unit-cell parameters are $a=7.0993(4), b=7.6370(5), c=7.7037(4) \AA, \alpha=79.58(1)^{\circ}$, $\beta=62.62(1)^{\circ}, \gamma=76.47(1)^{\circ} ; V=359.29(4) \AA^{3}, Z=1$. The strongest reflections on the X-ray powder diffraction pattern $[d, \AA(I, \%)(h k l)]$ are: $3.72(32)(020), 3.40(20)(002,021), 3.199(25)(012), 3.000(26),(012$,

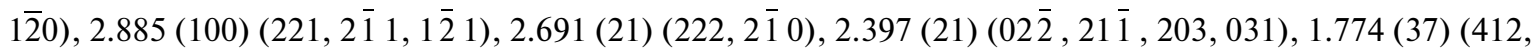
$3 \overline{2} 1)$. The type specimen is deposited in the Fersman Mineralogical Museum, Russian Academy of Sciences, Moscow, registration number 4420/1.

DOI: $10.1134 / \mathrm{S} 1075701515080048$

\section{INTRODUCTION}

Bustamite is frequently regarded as a mineral related to wollastonite or even as a wollastonite-group member (Ohashi and Finger, 1978; Back, 2014). This convergence is based on similar stoichiometry and conformation of the $\left(\mathrm{Si}_{3} \mathrm{O}_{9}\right)_{\infty}$ chains, or "dreierkette", after Grangeon et al. (2013). However, in terms of the

Corresponding author: N.V. Chukanov. E-mail: chukanov@icp.ac.ru

${ }^{1}$ A new mineral, mendigite, and its name were approved by the Commission on New Minerals, Nomenclature, and Classification of the International Mineralogical Association on May 1, 2014, IMA no. 2014-007. crystal structure, the affinity of these pyroxenoids is not very close.

The crystal structure of bustamite was published for the first time by Peacor and Buerger (1962). Later, Ohashi and Finger (1978) investigated the crystal structures of bustamite and wollastonite varieties different in composition and demonstrated substantial structural distinctions between these minerals. The crystal chemical formula of bustamite studied could be expressed as $M 1_{2} M 2_{2} M 3 M 4\left(\mathrm{Si}_{3} \mathrm{O}_{9}\right)_{2}$, where $\mathrm{Mn}^{2+}$ is predominant at sites $M 1$ and $M 3$, whereas sites $M 2$ and M4 are dominated by Ca (Peacor and Prewitt, 1963; Ohashi and Finger, 1978). 


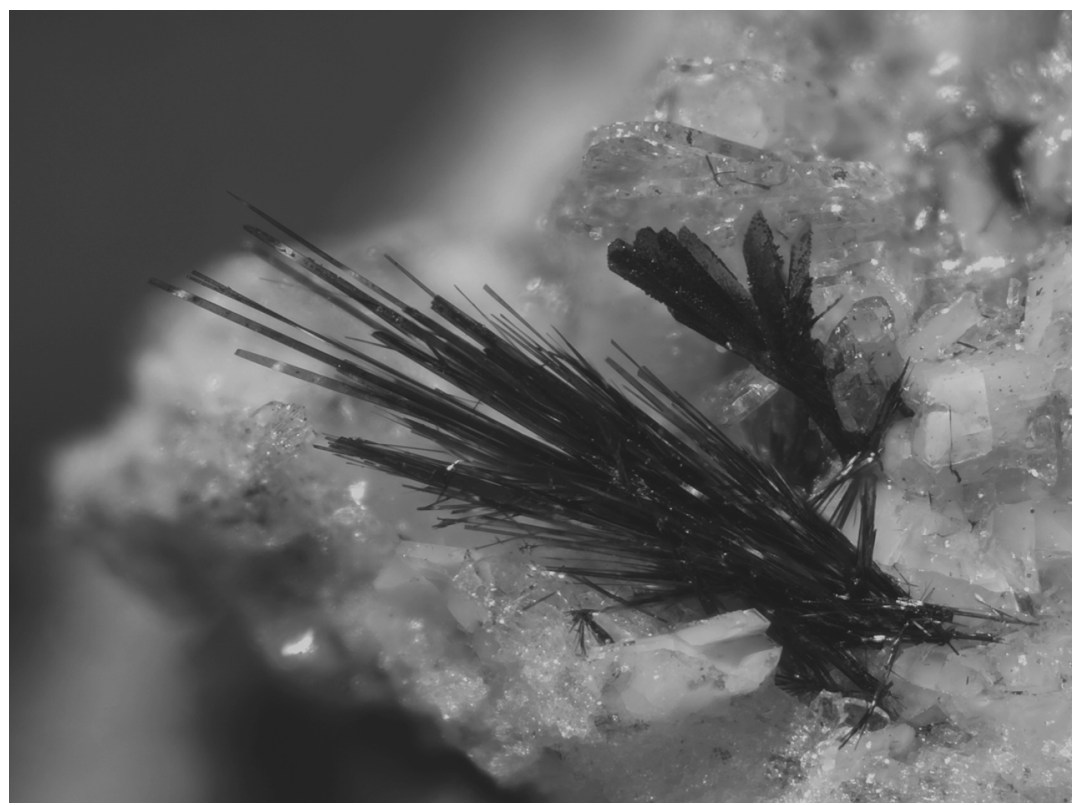

Fig. 1. Clusters of mendigite crystals on cavity wall within sanidinite. FOV $2.8 \mathrm{~mm}$. Photo by S. Wolfsried.

The new mineral, mendigite, described in this article is isostructural with bustamite, but differs in cation arrangement of structural sites. This mineral is named after its type locality near the town of Mendig in the Laacher Lake area, Eifel volcanic region, RhinelandPalatinate (Rheinland-Pfalz), Germany.

The type specimen is deposited in the Fersman Mineralogical Museum, Russian Academy of Sciences, Moscow, registration number 4420/1.

\section{OCCURRENCE}

The fragment of cavernous sanidinite with mendigite was found in the operating pumice quarry In den Dellen near the town of Mendig. The new mineral was found in a postmagmatic (probably pneumatolitic) paragenetic assemblage consisting of sanidine, nosean, rhodonite, tephroite, magnetite, and a pyrochlore group mineral. Crystals of these minerals occur in small miarolitic cavities within nearly monomineralic sanidinite.

Chukanov et al. (2014) discussed in detail the formation conditions of nosean-bearing sanidinite and related complex of various manganese minerals in the Laacher Lake area. Some researchers regard sanidinite as host metamorphic rock deeply altered at high $\mathrm{K}$ activity, whereas others workers regard it as a magmatic rock cogenetic to parental phonolite magma. In any case, host metamorphic rocks are the most probable source for Mn. In particular, this is indicated by striation (interpreted as a result of primary stratification) that is occasionally observed in the contact zone of sanidinite-containing miarolitic cavities with $\mathrm{Mn}$ minerals.

\section{MORPHOLOGY AND PHYSICAL PROPERTIES}

Mendigite occurs as imperfect long-prismatic crystals up to $0.1 \times 0.2 \times 2.5 \mathrm{~mm}$ in size (Fig. 1) flattened on $\{001\}$. Some crystals are polysynthetic twins parallel to (100); the constituents of twins are linked by the transfer matrix [100/1/2 $10 / 101]$.

The mineral is dark brown with a brown streak and strong vitreous luster. Perfect cleavage is parallel to (001). The calculated density is $3.56 \mathrm{~g} / \mathrm{cm}^{3}$.

Mendigite is optically biaxial negative, $\beta=1.782(5)$, $\gamma=1.796(5), 2 V=50(10)^{\circ}$. Due to a perfect cleavage, the measurement of $\alpha$ failed. The value estimated from average values of $\beta, \gamma$ and $2 V$ is 1.722 . The dispersion of optical axes is medium, $r>v$. The mineral is not pleochroic. The extinction angle is about $4-5^{\circ}$ relative to the crystal elongation (i.e., relative to [100]).

The IR spectrum of the mendigite powdery sample prepared as a pellet pressed with $\mathrm{KBr}$ (Fig. 2a) was measured using an ALPHA FTIR spectrometer, Bruker Optics, within the wavenumber range 360$3800 \mathrm{~cm}^{-1}$, at a resolution of $4 \mathrm{~cm}^{-1}$, and 16 scans. A pure $\mathrm{KBr}$ disc was used as a reference.

The position $\left(\mathrm{cm}^{-1}\right)$ and assignment of the bands in the IR spectrum of mendigite are as follows ( $\mathrm{s}$ is strong band, sh is shoulder): 1088s, 1030s, 945s, 907s ( $\mathrm{Si}-\mathrm{O}$ stretching vibrations), 694, 655, 564 (O-Si-O bending vibrations), 515, 461s, 445, 425sh (lattice modes involving $\mathrm{Si}-\mathrm{O}-\mathrm{Si}$ bending and $M \cdots \mathrm{O}$ stretching vibrations, where $M=\mathrm{Mn}, \mathrm{Fe}, \mathrm{Ca}$ ). Bands corresponding to $\mathrm{H}-$, $\mathrm{B}$ - and $\mathrm{C}$-bearing groups are absent in the IR spectrum of mendigite. The IR spectrum of mendigite is close to that bustamite (Fig, 2b); as com- 


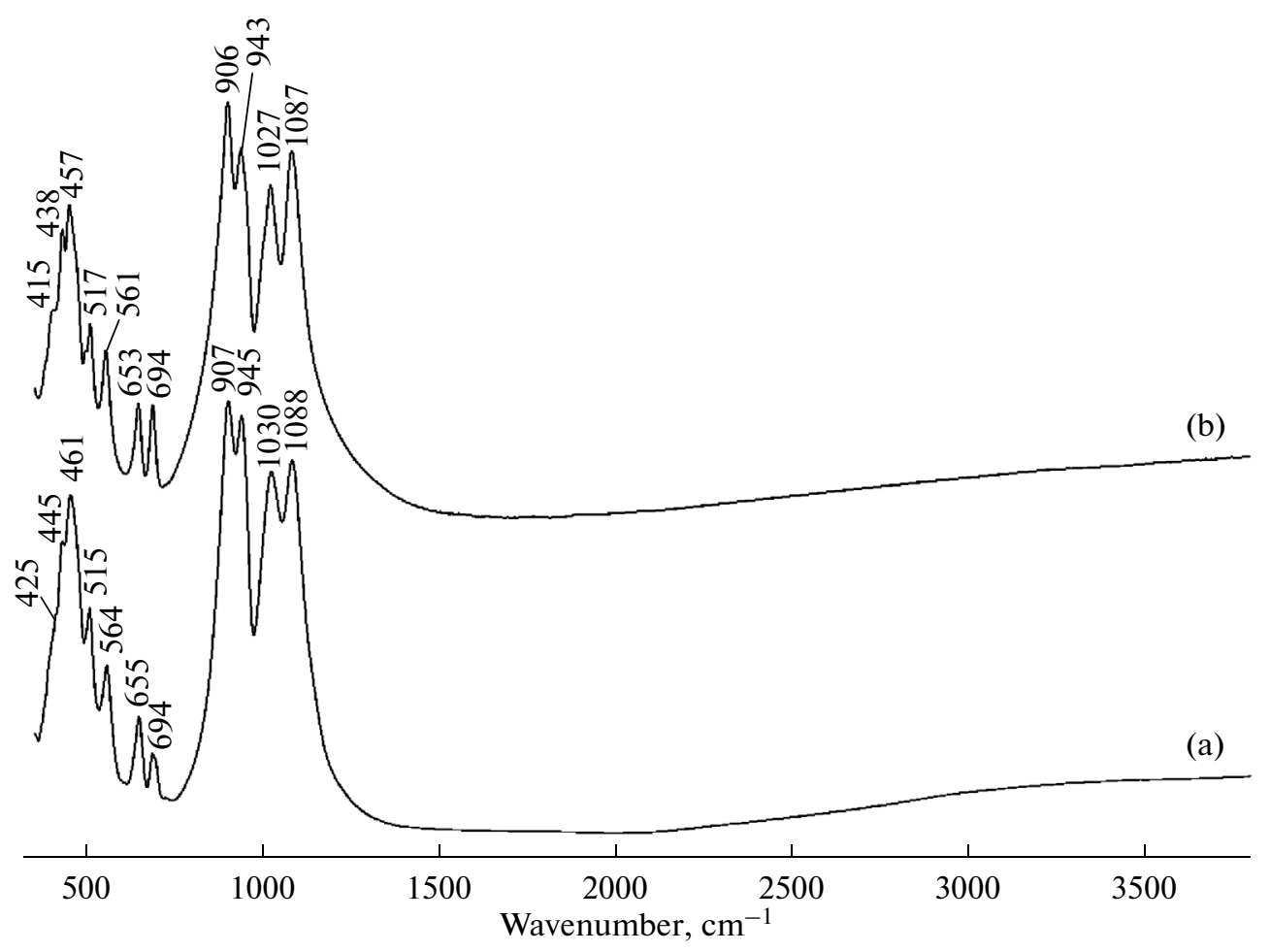

Fig. 2. IR spectra of (a) mendigite and (b) bustamite from Broken Hill, New South Wales, Australia.

pared with the latter, it is characterized by the highfrequency shifts of the most bands.

\section{CHEMICAL COMPOSITION}

The chemical composition of mendigite was determined on a Tescan Vega II XMU scanning electron microscope equipped with an INCAx-sight EDS operating on tungsten cathode at an accelerating voltage of $15.7 \mathrm{kV}$. The current of the absorbed electrons on Co was $0.5 \mathrm{nA}$. The take-off angle of $\mathrm{X}$-ray radiation was $35^{\circ}$, and the focal distance between sample and detector was $25 \mathrm{~mm}$.

The chemical composition (wt \%) is given in Table 1. The empirical formula of mendigite calculated on the basis of $12(\mathrm{Mg}+\mathrm{Ca}+\mathrm{Mn}+\mathrm{Al}+\mathrm{Fe}+$ $\mathrm{Si})$ atoms is $\left(\mathrm{Ca}_{1.47} \mathrm{Mn}_{4.03}^{2+} \mathrm{Mg}_{0.07} \mathrm{Mg}_{0.28}^{3+} \mathrm{Fe}_{0.15}^{3+}\right)_{6.00}$ $\left[\left(\mathrm{Si}_{5.57} \mathrm{Fe}_{0.27}^{3+} \mathrm{Al}_{0.16}\right)_{\Sigma 6.00} \mathrm{O}_{18}\right]$. Taking into acount structural data (see below), this formula could written as $\mathrm{Mn}_{2.00}\left(\mathrm{Mn}_{1.33} \mathrm{Ca}_{0.67}\right)\left(\mathrm{Mn}_{0.50}^{2+} \mathrm{Mg}_{0.28}^{3+} \mathrm{Fe}_{0.15}^{3+} \mathrm{Mg}_{0.07}\right)\left(\mathrm{Ca}_{0.80}\right.$ $\left.\mathrm{Mn}_{0.20}^{2+}\right)\left(\mathrm{Si}_{5.57} \mathrm{Fe}_{0.27}^{3+} \mathrm{Al}_{0.16} \mathrm{O}_{18}\right)$.

$\mathrm{Al}$ and a part of $\mathrm{Fe}^{3+}$ are placed in tetrahedral sites to the total of tetrahedral cations equal to 6 . Based on the charge-balance constraints for the bulk formula, trivalent state is accepted for all $\mathrm{Fe}$ at the octahedral sites and for a part of $\mathrm{Mn}\left(0.28 \mathrm{Mn}^{3+}\right.$ apfu). Substantial $\mathrm{Fe}^{3+}$ and $\mathrm{Mn}^{3+}$ contents are confirmed by very high refractive indices as compared to bustamite and by a good compatibility of physical properties and chemical composition calculated from the Gladstone-Dale equation $\left(1-\mathrm{K}_{\mathrm{p}} / \mathrm{K}_{\mathrm{c}}\right)=-0.037$ ("excellent"), whereas the assumption of a bivalent state for all $\mathrm{Fe}$ and/or Mn would result in poor compatibility.

The idealized formula of mendigite is $\mathrm{Mn}_{2} \mathrm{Mn}_{2} \mathrm{MnCa}\left(\mathrm{Si}_{3} \mathrm{O}_{9}\right)_{2}$.

Table 1. Chemical composition of mendigite (average of 4 point analyses)

\begin{tabular}{l|r|c|l}
\hline Component & $\begin{array}{c}\text { Content, } \\
\text { wt \% }\end{array}$ & Range & Standard \\
\hline $\mathrm{MgO}$ & 0.36 & $0.25-0.49$ & Diopside \\
$\mathrm{CaO}$ & 10.78 & $10.11-10.92$ & Wollastonite \\
$\mathrm{MnO} *$ & 37.47 & $39.37-40.80 * *$ & $\mathrm{MnTiO}_{3}$ \\
$\mathrm{Mn}_{2} \mathrm{O}_{3} *$ & 2.91 & & \\
$\mathrm{Fe}_{2} \mathrm{O}_{3}$ & 4.42 & $4.15-4.70$ & $\mathrm{Fe}_{2} \mathrm{O}_{3}$ \\
$\mathrm{Al}_{2} \mathrm{O}_{3}$ & 1.08 & $0.87-1.28$ & $\mathrm{Albite}$ \\
$\mathrm{SiO}_{2}$ & 43.80 & $43.24-44.54$ & $\mathrm{SiO}_{2}$ \\
$\mathrm{Total}$ & 100.82 & & \\
\hline
\end{tabular}

* Total manganese (corresponding to $40.09 \mathrm{wt} \% \mathrm{MnO}$ ) was apportioned between $\mathrm{MnO}$ and $\mathrm{Mn}_{2} \mathrm{O}_{3}$ taking into account structural data and charge balance constraints in the empirical formula.

** For total manganese calculated as MnO. 
Table 2. Powder X-ray diffraction data for mendigite

\begin{tabular}{|c|c|c|c|c|}
\hline$I_{\text {meas }}$ & $d_{\text {meas }}$ & $I_{\text {calc }^{*}}$ & $d_{\text {calc }} * *$ & $h k l$ \\
\hline 8 & 4.84 & 13 & 4.813 & $01 \overline{1}$ \\
\hline 12 & 4.40 & 10 & 4.397 & $1 \overline{1} 0$ \\
\hline 32 & 3.72 & 27 & 3.699 & 020 \\
\hline 20 & 3.40 & 32,5 & $3.408,3.373$ & 002,021 \\
\hline 25 & 3.199 & 47 & 3.200 & 012 \\
\hline 26 & 3.000 & 47,5 & $3.000,2.961$ & $01 \overline{2}, 1 \overline{2} 0$ \\
\hline 100 & 2.885 & $100.92,5$ & $2.883,2.879,2.867$ & $221,2 \overline{1} 1,1 \overline{2} 1$ \\
\hline 21 & 2.691 & 4,7 & $2.703,2.701$ & 222,210 \\
\hline 12 & 2.622 & 16 & 2.620 & 022 \\
\hline 13 & 2.464 & $18,7,7$ & $2.466,2.450,2.449$ & $030,20 \overline{1}, 213$ \\
\hline 21 & 2.397 & $10,11,14,1$ & $2.407,2.403,2.400,2.385$ & $02 \overline{2}, 21 \overline{1}, 203,031$ \\
\hline 13 & 2.272 & $8,1,2,11,2,3,2$ & $\begin{array}{l}2.275,2.273,2.272, \quad 2.271 \\
2.259,2.256,2.256\end{array}$ & $231,1 \overline{1} 3,003,2 \overline{2} 1,03 \overline{1}, 223,2 \overline{11}$ \\
\hline 17 & 2.227 & 29 & 2.226 & 013 \\
\hline 18 & 2.112 & 19,17 & $2.117,2.113$ & $230,2 \overline{2} 2$ \\
\hline 37 & 1.774 & 34,2 & $1.775,1.773$ & $412,3 \overline{2} 1$ \\
\hline 10 & 1.703 & 20 & 1.704 & 004 \\
\hline 19 & 1.659 & $11,11,9,8$ & $1.662,1.662,1.654,1.653$ & $234,2 \overline{22}, 243,2 \overline{31}$ \\
\hline 14 & 1.554 & $7,7,4,6$ & $1.558,1.555,1.552,1.552$ & $24 \overline{1}, 2 \overline{3} 3,400,424$ \\
\hline 5 & 1.480 & $3,4,3$ & $1.482,1.481,1.480$ & $252,2 \overline{4} 0,050$ \\
\hline 4 & 1.427 & 2,3 & $1.430,1.427$ & $430,4 \overline{1} 4$ \\
\hline 3 & 1.349 & $1,1,4$ & $1.352,1.351,1.349$ & $444,4 \overline{2} 0,03 \overline{4}$ \\
\hline 6 & 1.318 & 2,7 & $1.322,1.317$ & $2 \overline{2} 5,05 \overline{2}$ \\
\hline 3 & 1.291 & $1,3,1,1$ & $1.293,1.291,1.291,1.290$ & $5 \overline{1} 3,053,245,2 \overline{33}$ \\
\hline 2 & 1.232 & $4,5,5$ & $1.232,1.230,1.229$ & $061,41 \overline{2}, 416$ \\
\hline
\end{tabular}

* Only reflections with intensities $\geq 1$ are given.

** Calculated from single-crystal data.

\section{X-RAY CRYSTALLOGRAPHY}

The powder X-ray diffraction data of mendigite (Table 2) were collected using an Agilent Technologies Super-Nova diffractometer with an Atlas CCD detector operating at $\mathrm{Cu} K_{\alpha}$ radiation (microfocusing instrument was used), accelerating voltage $50 \mathrm{kV}$, and current intensity $0.8 \mathrm{~mA}$. The experiment has been carried out using the Gandolfi method; the distance between sample and detector was $55 \mathrm{~mm}$. All reflections of the mineral X-ray diffraction pattern are indexed in the triclinic cell with the following unit-cell parameters refined from the powder data: $a=7.11(2)$, $b=7.65(2), c=7.70(2) \AA, \alpha=79.54(8)^{\circ}, \beta=$ $62.65(8)^{\circ}, \gamma=76.32(9)^{\circ}, V=359.8(7) \AA^{3}$.

Single-crystal X-ray data were collected in a full sphere of reciprocal space on an Xcalibur Oxford Diffraction CCD diffractometer (Mo $K_{\alpha}$ radiation). The calculated triclinic unit cell parameters (space group $P \overline{1}$ ) are as follows: $a=7.0993(4), b=7.6370(5), c=$ 7.7037(4) $\AA, \alpha=79.58(1)^{\circ}, \beta=62.62(1)^{\circ}, \gamma=$ 76.47(1) $)^{\circ}, V=359.29(4) \AA^{3}, Z=1$. The transition from primitive unit cell with $a=7.0993(4), b=$ 7.6370(5), $c=7.7037(4) \AA, \alpha=79.58(1)^{\circ}, \beta=$ $62.62(1)^{\circ}, \gamma=76.47(1)^{\circ}$ (space group $P \overline{1}$ ) to the body- 
Table 3. Crystallographic data and refinement details for mendigite

\begin{tabular}{|c|c|}
\hline Formula & $\mathrm{Mn}_{2}\left(\mathrm{Mn}_{1.33} \mathrm{Ca}_{0.67}\right)\left(\mathrm{Mn}_{0.78} \mathrm{Fe}_{0.15} \mathrm{Mg}_{0.07}\right)\left(\mathrm{Ca}_{0.8} \mathrm{Mn}_{0.2}\right)\left(\mathrm{Si}_{3} \mathrm{O}_{9}\right)_{2}$ \\
\hline Absorption, $\mu, \mathrm{mm}^{-1}$ & 5.24 \\
\hline Density, $D_{x}, \mathrm{~g} / \mathrm{cm}^{3}$ & 3.56 \\
\hline Space group & $P \overline{1}$ \\
\hline$a(\AA)$ & $7.0993(4)$ \\
\hline$b(\AA)$ & $7.6370(5)$ \\
\hline$c(\AA)$ & $7.7037(4)$ \\
\hline$\alpha\left(^{\circ}\right)$ & $79.58(1)$ \\
\hline$\beta\left(\left(^{\circ}\right)\right.$ & $62.62(1)$ \\
\hline$\gamma\left(\left(^{\circ}\right)\right.$ & $76.47(1)$ \\
\hline$V\left(\AA^{3}\right)$ & $359.29(4)$ \\
\hline Crystal size, $\mathrm{mm}$ & $0.75 \times 0.05 \times 0.05$ \\
\hline Diffractometer & Xcalibur Oxford Diffraction (CCD-detector) \\
\hline Radiation; wavelength, Å & $\operatorname{Mo}_{\alpha}, 0.7107$ \\
\hline Data collection method & $\omega$ \\
\hline Temperature, $\mathrm{K}$ & 293 \\
\hline$F(000)$ & 373 \\
\hline$\theta$ range for data, degree & $4.23-56.11$ \\
\hline Index ranges $h, k, l$ & $-9<h<15,-17<k<17,-17<l<17$ \\
\hline Total reflections & 19616 \\
\hline Number of unique reflections & 7567 \\
\hline Number of unique reflectons with $I>3 \sigma(I)$ & 4144 \\
\hline$R$ value of averaged equivalent reflections & 8.03 \\
\hline Refinement method & Full-matrix least-squares on $F$, with weights $w=1 /\left(\sigma^{2} F+0.0016 F^{2}\right)$ \\
\hline GOF & 1.06 \\
\hline$R_{1} / w R_{2}(\%)$ & $0.0559 / 0.091$ \\
\hline$\Delta \rho_{\min } / \Delta \rho_{\max }$ & $-2.35 / 1.86$ \\
\hline Calculation programs & Jana2006, AREN \\
\hline
\end{tabular}

$R_{1}=\Sigma|| F_{\text {obs }}|-| F_{\text {calc }}|| \Sigma\left|F_{\text {obs }}\right|, \quad w R_{2}=\left\{\Sigma\left[w\left(F_{\text {obs }}^{2}-F_{\text {calc }}^{2}\right)^{2}\right] / \Sigma\left[w\left(F_{\text {obs }}^{2}\right)^{2}\right]\right\}^{1 / 2}$, GOF $=\left\{\Sigma\left[w\left(F_{\text {obs }}^{2}-F_{\text {calc }}^{2}\right)\right] /(n-p)\right\}^{1 / 2}$, where $n$ is number of reflections, $p$ is number of refined parameters 
Table 4. Atom coordinates, repetition factor of sites $(Q)$ and isotropic displacement parameters $\left(U_{\text {eq }}\right)$ for the crystal structure of mendigite

\begin{tabular}{|c|c|c|c|c|c|}
\hline Site & $x$ & $y$ & $z$ & Q & Ueq \\
\hline$M 1$ & $-0.0501(1)$ & $0.2049(1)$ & $0.2530(1)$ & $2 i$ & $0.0105(1)$ \\
\hline$M 2$ & $-0.4364(1)$ & $0.7963(1)$ & $0.7518(1)$ & $2 i$ & $0.0138(1)$ \\
\hline$M 3$ & 0 & 0.5 & 0.5 & $1 g$ & $0.0078(1)$ \\
\hline$M 4$ & 0.5 & 0.5 & 0.5 & $1 h$ & $0.0065(2)$ \\
\hline Sil & $-0.2458(1)$ & $0.8263(1)$ & $0.2710(1)$ & $2 i$ & $0.0060(2)$ \\
\hline $\mathrm{Si} 2$ & $-0.3157(1)$ & $0.1755(1)$ & $0.7384(1)$ & $2 i$ & $0.0058(2)$ \\
\hline $\mathrm{Si} 3$ & $0.2001(1)$ & $0.6053(1)$ & $0.0408(1)$ & $2 i$ & $0.0060(2)$ \\
\hline $\mathrm{O} 1$ & $0.0060(2)$ & $0.4298(2)$ & $0.1954(2)$ & $2 i$ & $0.0092(5)$ \\
\hline $\mathrm{O} 2$ & $-0.1979(5)$ & $0.2990(3)$ & $0.5418(3)$ & $2 i$ & $0.0165(7)$ \\
\hline $\mathrm{O} 3$ & $-0.0312(3)$ & $0.7445(3)$ & $0.0793(3)$ & $2 i$ & $0.0119(5)$ \\
\hline $\mathrm{O} 4$ & $0.3152(4)$ & $0.5931(2)$ & $-0.1916(2)$ & $2 i$ & $0.0106(5)$ \\
\hline O5 & $-0.2191(6)$ & $0.9648(3)$ & $0.7464(4)$ & $2 i$ & $0.0218(9)$ \\
\hline O6 & $-0.2615(5)$ & $0.6914(3)$ & $0.4645(3)$ & $2 i$ & $0.0147(6)$ \\
\hline O7 & $0.3430(4)$ & $0.7301(3)$ & $0.0729(3)$ & $2 i$ & $0.0117(6)$ \\
\hline $\mathrm{O} 8$ & $-0.2665(6)$ & $0.0346(3)$ & $0.2910(4)$ & $2 i$ & $0.0219(8)$ \\
\hline O9 & $-0.4415(5)$ & $0.8079(7)$ & $0.2276(5)$ & $2 i$ & $0.044(2)$ \\
\hline
\end{tabular}

$U_{\text {eq }}$ is defined as one third of the orthogonalized $U_{i j}$ tensor trace.

centered unit cell proposed by Ohashi and Finger (1978) may be realized using the matrix $[0 \overline{1} 1 / 1 \overline{1} / \overline{1} 00]$.

The structure was determined with the "charge flipping" procedure using the SUPERFLIP program (Palatinus and Chapuis, 2007). Because of the complex chemical composition, cation distribution through the structural sites was performed based on crystal chemical criteria taking into account displacement parameters, interatomic distances, ionic radii of the cations, and controlling $R$ values. The mixed curves of atomic scattering were used for a number of sites. The model was refined to final $R=5.59 \%$ using 4144 unique reflections with $I>I \sigma(I)$ in the anisotropic approximation taking into account the twinning (twinning matrix $[100 / 1 / 2 \overline{1} 0 / 20 / 101]$, the ratio of two twin components $0.6: 0.4$ ). All calculations were per- formed with the JANA2006 (Petricek et al., 2006) and AREN (Andrianov, 1987) crystallographic software packages.

The crystallographic data, details of single-crystal experiment, and results of the mendigite structural analysis are given in Tables 3-6.

Mendigite is isostructural with bustamite and ferrobustamite. The crystal structure of these minerals, which may be combined into the bustamite group, is based on triple-row bands of $M$ cations and wollastonitetype chains of $\mathrm{SiO}_{4}$ tetrahedra (Figs. 3-5).

The following distribution of cations by sites $M$ (assumed cation assignment is given in brackets taking into account the electron microprobe data) was obtained as a result of refinement taking into account the cation-oxygen distances: $M 1-$ only $\mathrm{Mn}^{2+}$ $\left[\mathrm{Mn}^{2+}\right] ; M 2-\mathrm{Mn}^{2+}$ with minor $\mathrm{Ca}\left[\mathrm{Mn}_{1.33}^{2+} \mathrm{Ca}_{0.67}\right]$; 
Table 5. Anisotropic displacement parameters $\left(\AA^{2}\right)$ for mendigite

\begin{tabular}{l|l|l|l|l|r|r}
\hline Site & $U_{11}$ & $U_{22}$ & $U_{33}$ & $U_{12}$ & $U_{13}$ & $U_{23}$ \\
\hline$M 1$ & $0.0113(2)$ & $0.0098(1)$ & $0.0095(1)$ & $0.0001(1)$ & $-0.0042(1)$ & $-0.0018(1)$ \\
$M 2$ & $0.0099(2)$ & $0.0171(2)$ & $0.0107(1)$ & $-0.0034(1)$ & $-0.0007(1)$ & $-0.0020(1)$ \\
$M 3$ & $0.0068(2)$ & $0.0089(1)$ & $0.0076(1)$ & $-0.0029(2)$ & $-0.0025(2)$ & $-0.0006(1)$ \\
$M 4$ & $0.0033(2)$ & $0.0097(2)$ & $0.0076(2)$ & $-0.0018(2)$ & $-0.0022(2)$ & $-0.0031(1)$ \\
Si1 & $0.0024(2)$ & $0.0074(2)$ & $0.0077(2)$ & $-0.0016(2)$ & $-0.0017(2)$ & $0.0002(2)$ \\
Si2 & $0.0041(3)$ & $0.0069(2)$ & $0.0068(2)$ & $-0.0020(2)$ & $-0.0023(2)$ & $-0.0003(2)$ \\
Si3 & $0.0041(3)$ & $0.0080(2)$ & $0.0052(2)$ & $-0.0020(2)$ & $-0.0014(2)$ & $0.0003(1)$ \\
O1 & $0.0104(8)$ & $0.0069(4)$ & $0.0076(4)$ & $-0.0022(5)$ & $-0.0019(5)$ & $0.0012(3)$ \\
O2 & $0.028(1)$ & $0.0130(6)$ & $0.0073(5)$ & $-0.0132(8)$ & $-0.0025(7)$ & $0.0011(5)$ \\
O3 & $0.0045(7)$ & $0.0138(7)$ & $0.0105(6)$ & $0.0026(5)$ & $0.0000(5)$ & $0.0007(5)$ \\
O4 & $0.0106(8)$ & $0.0104(5)$ & $0.0074(5)$ & $-0.0031(6)$ & $-0.0004(6)$ & $-0.0010(4)$ \\
O5 & $0.031(2)$ & $0.0100(6)$ & $0.0207(9)$ & $0.0086(8)$ & $-0.014(1)$ & $-0.0020(6)$ \\
O6 & $0.0131(9)$ & $0.0127(6)$ & $0.0092(5)$ & $0.0016(6)$ & $-0.0002(6)$ & $0.0032(4)$ \\
O7 & $0.0152(9)$ & $0.0164(7)$ & $0.0074(5)$ & $-0.0093(6)$ & $-0.0053(5)$ & $-0.0006(5)$ \\
O8 & $0.024(1)$ & $0.0100(6)$ & $0.0208(8)$ & $-0.0078(8)$ & $0.0024(9)$ & $-0.0033(6)$ \\
O9 & $0.009(1)$ & $0.096(3)$ & $0.037(2)$ & $-0.008(2)$ & $-0.009(1)$ & $-0.037(2)$ \\
\hline
\end{tabular}

Table 6. Selected interatomic distances $(\AA)$ in mendigite

\begin{tabular}{|c|c|c|c|c|c|}
\hline \multirow[t]{7}{*}{$M 1$} & O5 & $2.045(4)$ & \multirow[t]{7}{*}{$M 4$} & O4 & $2.276(1) \times 2$ \\
\hline & O8 & $2.126(4)$ & & O6 & $2.380(3) \times 2$ \\
\hline & $\mathrm{O} 2$ & $2.156(2)$ & & $\mathrm{O} 2$ & $2.444(3) \times 2$ \\
\hline & O4 & $2.311(2)$ & & O9 & $2.824(4) \times 2$ \\
\hline & $\mathrm{O} 3$ & $2.328(2)$ & & Average & 2.481 \\
\hline & $\mathrm{O} 1$ & $2.412(3)$ & & & \\
\hline & Average & 2.230 & & & \\
\hline \multirow[t]{7}{*}{$M 2$} & O6 & $2.175(2)$ & \multirow[t]{7}{*}{ Sil } & O8 & $1.592(3)$ \\
\hline & O5 & $2.211(4)$ & & O9 & $1.612(5)$ \\
\hline & O7 & $2.211(4)$ & & O6 & $1.625(2)$ \\
\hline & $\mathrm{O} 8$ & $2.332(4)$ & & $\mathrm{O} 3$ & $1.647(2)$ \\
\hline & $\mathrm{O} 1$ & $2.401(2)$ & & Average & 1.619 \\
\hline & O4 & $2.457(3)$ & & & \\
\hline & Average & 2.309 & & & \\
\hline \multirow[t]{10}{*}{$M 3$} & O6 & $2.170(3) \times 2$ & \multirow[t]{5}{*}{$\mathrm{Si}_{2}$} & O5 & $1.597(2)$ \\
\hline & $\mathrm{O} 1$ & $2.192(1) \times 2$ & & O9 & $1.597(4)$ \\
\hline & $\mathrm{O} 2$ & $2.202(3) \times 2$ & & $\mathrm{O} 2$ & $1.603(2)$ \\
\hline & Average & 2.188 & & O7 & $1.650(3)$ \\
\hline & & & & Average & 1.612 \\
\hline & & & \multirow[t]{5}{*}{$\mathrm{Si}_{3}$} & O4 & $1.600(2)$ \\
\hline & & & & O1 & $1.607(2)$ \\
\hline & & & & $\mathrm{O} 3$ & $1.663(2)$ \\
\hline & & & & O7 & $1.663(3)$ \\
\hline & & & & Average & 1.633 \\
\hline
\end{tabular}




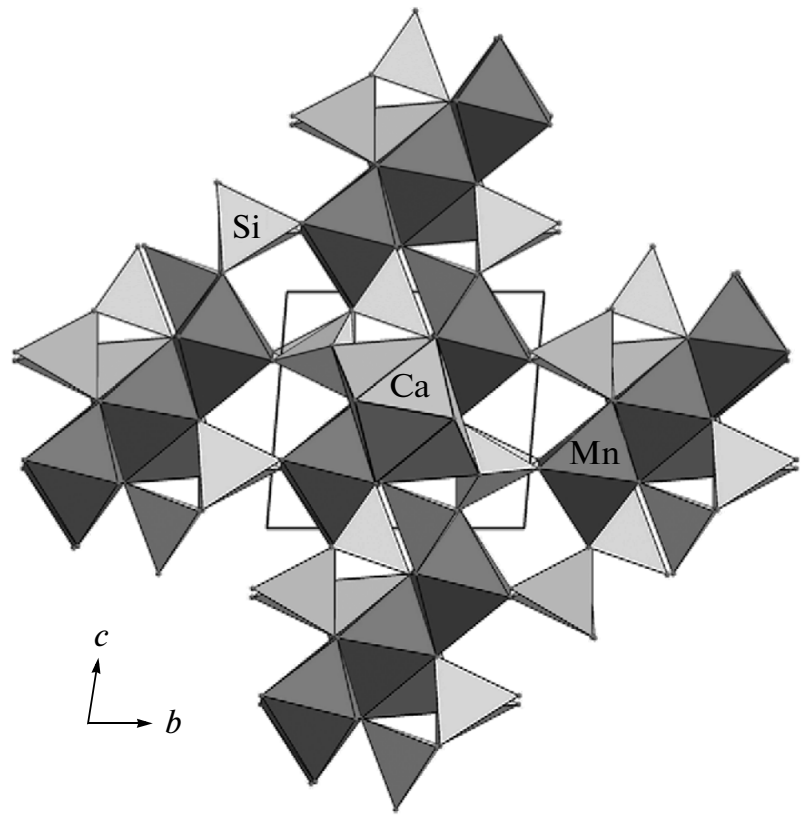

Fig. 3. Crystal structure of mendigite projected on (100) plane.

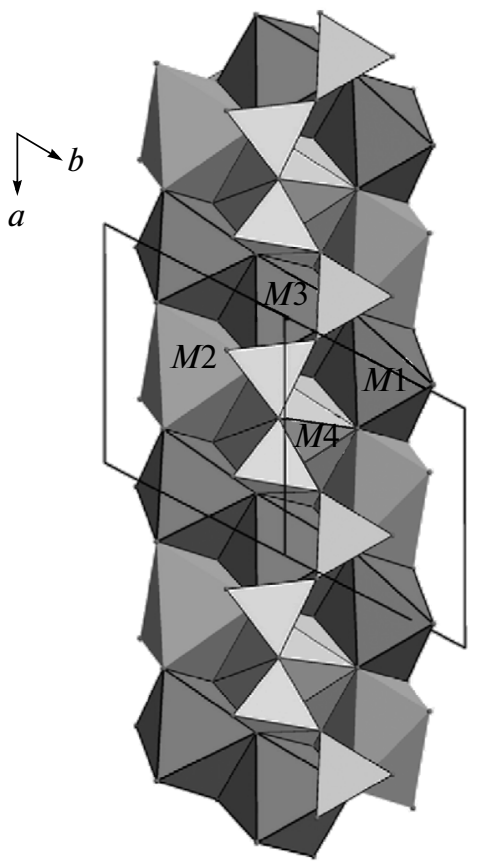

Fig. 4. Triple-row band of mendigite formed by $M 1-M 4$ polyhedra.

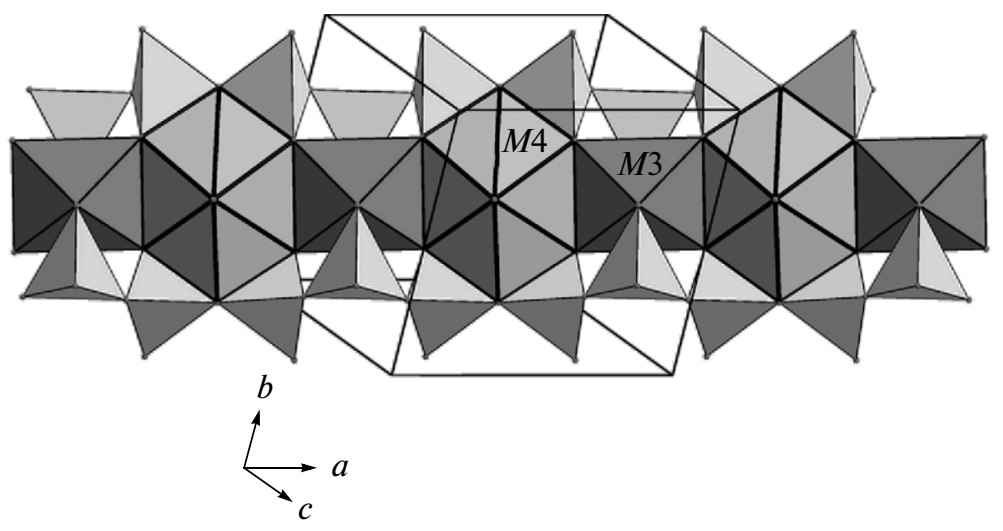

Fig. 5. Silicate chains in mendigite and their linkage to the octahedral band.

$\mathrm{M3}-\mathrm{Mn}^{2+}$ with minor $\mathrm{Mn}^{3+}, \mathrm{Fe}^{3+}$, and $\mathrm{Mg}$ $\left[\mathrm{Mn}_{0.50}^{2+} \mathrm{Mn}_{0.28}^{3+} \mathrm{Fe}_{0.15}^{3+} \mathrm{Mg}_{0.07}\right]$; and $M 4-\mathrm{Ca}$ with admixture of $\mathrm{Mn}^{2+}\left[\mathrm{Ca}_{0.80} \mathrm{Mn}_{0.20}^{2+}\right]$.

\section{DISCUSSION}

The major difference between the structural types of bustamite and wollastonite is the linkage of tetrahedral chains to the system of $M$-polyhedra (Peacor and Prewitt, 1963; Ohashi and Finger, 1978; Angel, 1985, 1986). This difference is illustrated in Fig. 6.

The structural type of bustamite is characterized by four cation sites $M 1, M 2, M 3$, and $M 4$ with coordina- tion numbers $6,6,6$, and $6+2$, respectively (in the polyhedron $M 4$, two cation-oxygen distances are substantially longer than the other six cation-oxygen distances). In wollastonite-type structure only three cation sites $M 1, M 2$, and $M 3$ with coordination numbers 6,6 , and 7, respectively, are present.

The bustamite group members differ in the arrangement of cations at $M$-sites. In ferrobustamite, $\mathrm{Ca}_{2} \mathrm{Ca}_{2} \mathrm{FeCa}\left(\mathrm{Si}_{3} \mathrm{O}_{9}\right)_{2}$ (Burnham, 1975; Yamanaka et al., 1977) $\mathrm{Fe}^{2+}$ is predominant in the small M3 octahedron, whereas at the other $M$ sites, $\mathrm{Ca}$ is predominant. Bustamite, $\mathrm{Mn}_{2} \mathrm{Ca}_{2} \mathrm{MnCa}\left(\mathrm{Si}_{3} \mathrm{O}_{9}\right)_{2}$ and mendigite $\mathrm{Mn}_{2} \mathrm{Mn}_{2} \mathrm{MnCa}\left(\mathrm{Si}_{3} \mathrm{O}_{9}\right)_{2}$ differ in cation predominant at the site $M 2$ (Ca and $\mathrm{Mn}^{2+}$, respectively). The 
(a)

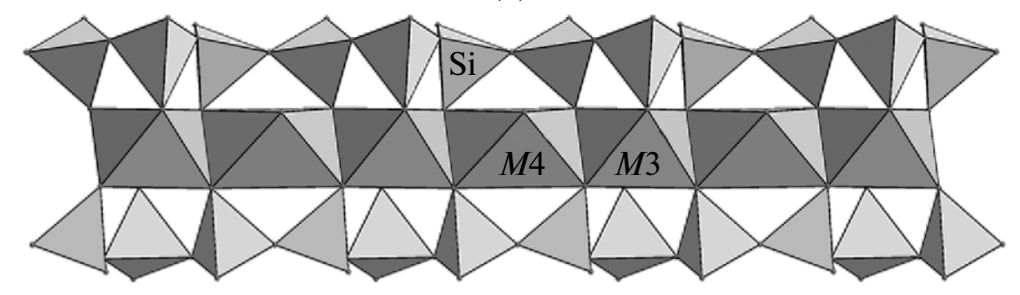

(b)

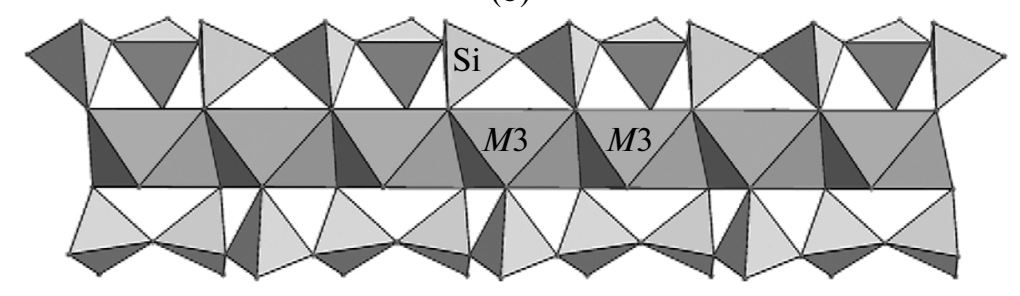

Fig. 6. Linkage of wollastonite-type silicate chains to octahedral bands in the crystal structures of (a) bustamite and (b) wollastonite.

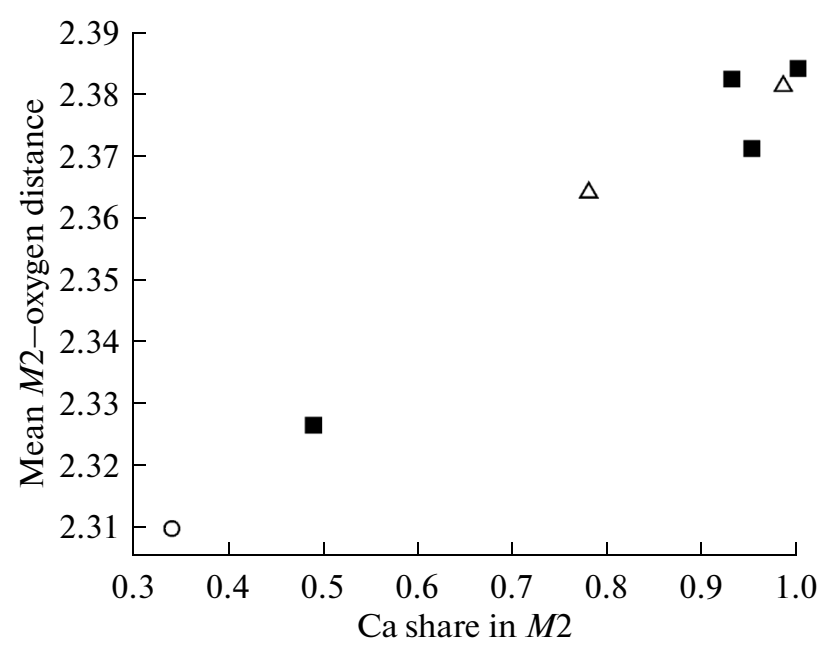

Fig. 7. Correlation between mean $M 2-$ oxygen distance and fractional Ca content at $M 2$ site. Squares correspond to bustamite and "manganoan bustamite" (Peacor and Buerger, 1962; Ohashi and Finger, 1978); triangles correspond to ferrobustamite (Rapoport and Burnham, 1973; Yamanaka et al., 1977), and circle corresponds to mendigite.

predominance of $\mathrm{Mn}$ over $\mathrm{Ca}$ at the site $M 2$ in mendigite is supported by the average distance $M 2-\mathrm{O}$. As follows from correlation between this value and a fraction of $\mathrm{Ca}$ at the $M 2$ site obtained by means of X-ray structural analysis (Fig. 7), the $\mathrm{Mn}^{2+} / \mathrm{Ca}$ ratio at site $M 2$ of mendigite is close to 2 .

As is seen from available compositional data for minerals with a bustamite-type structure (Mason, 1975; Ohashi and Finger, 1978; Minerals, 1981), mendigite is extremely rare in nature. In addition to the holotype sample described in this paper, only one natural sample is known, for which the insignificant predominance of $\mathrm{Mn}$ over $\mathrm{Ca}$ at the site $M 2\left(\mathrm{Mn}^{2+}: \mathrm{Ca}=\right.$
51 : 49) could be assumed. It comes from a lens of manganese ore hosted in dolomite marble of the Mitsuka deposit, Japan (Ohashi and Finger, 1978).

Comparative data for mendigite and related minerals are given in Table 7. It should be emphasized that the new mineral substantially differs from bustamite and ferrobustamite in optical parameters and density.

\section{ACKNOWLEDGMENTS}

This study was supported by the Russian Science Foundation (project no. 14-17-00048) with regard to mineralogical investigations, and Russian Foundation 
Table 7. Comparative data for bustamite-mendigite group members, bustamite and ferrobustamite

\begin{tabular}{|c|c|c|c|}
\hline Mineral & Mendigite & Bustamite & Ferrobustamite \\
\hline Formula & $\mathrm{Mn}_{2} \mathrm{Mn}_{2} \mathrm{MnCa}\left(\mathrm{Si}_{3} \mathrm{O}_{9}\right)_{2}$ & $\mathrm{Mn}_{2} \mathrm{Ca}_{2} \mathrm{MnCa}\left(\mathrm{Si}_{3} \mathrm{O}_{9}\right)_{2}$ & $\mathrm{Ca}_{2} \mathrm{Ca}_{2} \mathrm{FeCa}\left(\mathrm{Si}_{3} \mathrm{O}_{9) 2}\right.$ \\
\hline Simplified formula & $\mathrm{Mn}_{5} \mathrm{Ca}\left(\mathrm{Si}_{3} \mathrm{O}_{9}\right)_{2}$ & $\mathrm{Mn}_{3} \mathrm{Ca}_{3}\left(\mathrm{Si}_{3} \mathrm{O}_{9}\right)_{2}$ & $\mathrm{Ca}_{5} \mathrm{Fe}\left(\mathrm{Si}_{3} \mathrm{O}_{9}\right)_{2}$ \\
\hline Symmetry & Triclinic, $P \overline{1}$ & Triclinic, $P \overline{1}$ & Triclinic, $P \overline{1}$ \\
\hline$a, \AA$ & 7.0993 & 7.139 & 7.253 \\
\hline$b, \AA$ & 7.6370 & 7.719 & 7.862 \\
\hline$c, \AA$ & 7.7037 & 7.747 & 7.900 \\
\hline$\alpha, \circ$ & 79.58 & 79.257 & 79.23 \\
\hline$\beta, \circ$ & 62.62 & 63.074 & 62.117 \\
\hline$\gamma, \circ$ & 76.47 & 76.175 & 76.710 \\
\hline$V, \AA^{3}$ & 359.3 & 368.0 & 385.9 \\
\hline$Z$ & 1 & 1 & 1 \\
\hline Strong lines of the powder & $3.72(32)$ & $3.19(50)$ & $7.67(25)$ \\
\hline \multirow[t]{7}{*}{$\mathrm{X}$-ray: $d, \AA(I, \%)$} & $3.40(20)$ & $2.989(60)$ & $3.84(55)$ \\
\hline & $3.199(25)$ & $2.880(100)$ & $3.470(60)$ \\
\hline & $3.000(26)$ & $2.711(30)$ & $3.270(100)$ \\
\hline & $2.885(100)$ & $2.227(40)$ & $3.049(80)$ \\
\hline & $2.691(21)$ & $1.776(50)$ & $2.696(30)$ \\
\hline & $2.397(21)$ & $1.665(40)$ & $2.278(65)$ \\
\hline & $1.774(37)$ & & \\
\hline \multicolumn{4}{|l|}{ Optical data: } \\
\hline$\alpha$ & 1.722 (calc.) & $1.640-1.695$ & 1.640 \\
\hline$\beta$ & 1.782 & $1.651-1.708$ & No data \\
\hline$\gamma$ & 1.796 & $1.680-1.710$ & 1.653 \\
\hline Optical sign, $2 \mathrm{~V}, \circ$ & -50 & $-(34-60)$ & -60 \\
\hline Density, $\mathrm{g} / \mathrm{cm}^{3}$ & 3.56 & $3.32-3.46$ & 3.09 \\
\hline Source & This study & $\begin{array}{l}\text { Ohashi, Finger, 1978; } \\
\text { Deer et al., 1978; } \\
\text { Harada et al., 1974; } \\
\text { Minerals (1981) }\end{array}$ & $\begin{array}{l}\text { Deer et al., 1978; } \\
\text { Yamanaka et al., 1977; Rapo- } \\
\text { port, Burnham, 1973; Shi- } \\
\text { mazaki, Tanaka, 1973; Minerals } \\
\text { (1981) }\end{array}$ \\
\hline
\end{tabular}

Unit-cell parameters are given in the unified orientation accepted in this work. Unit-cell parameters given for bustamite by Ohashi and Finger (1978) are $a=9.864, b=10.790, c=7.139 \AA, \alpha=99.53, \beta=99.71, \gamma=83.83^{\circ}$. Matrix of transition to new cell is $[00-1,-1 / 2-$ $1 / 2-1 / 2,1 / 2-1 / 2-1 / 2]$. Unit-cell parameters of ferrobustamite published by Yamanaka et al. (1977) are: $a=7.862, b=7.253, c=13.967 \AA$, $\alpha=89.44, \beta=95.28, \gamma=103.29^{\circ}$. The corresponding transition matrix is $\left[\begin{array}{lllll}0 & -1 & 0,1 & 0 & 0,0-1 / 2-1 / 2\end{array}\right]$.

for Basic Research (project no. 14-05-00190) and Council for Grants of the President of the Russian Federation (project MK-4990.2014.5) with regard to crystal chemical investigation.

\section{REFERENCES}

Andrianov, V.I., Development of the system of crystallographic programs RENTGEN for the computers NORD, SM-4 and US, Kristallografiya, 1987, vol. 32, pp. 228-231. Angel, R.J. Structural variation in wollastonite and bustamite, Mineral. Mag., 1985, vol. 49, pp. 37-48.

Angel, R.J., Transformation mechanisms between singlechain silicates, Am. Mineral., 1986, vol. 71, pp. 1441-1454.
Brown, I.D. and Altermatt, D. Bond-valence parameters obtained from a systematic analysis of the Inorganic Crystal Structure Database, Acta Crystallogr., 1985, vol. 41, pp. 244-247.

Burnham, C.W., Ferrobustamite: the crystal structures of two $\mathrm{Ca}, \mathrm{Fe}$ bustamite-type pyroxenoids: correction, Z. Kristallogr., 1975, vol. 142, pp. 450-452.

Chukanov, N.V., Krivovichev, S.V., Pakhomova, A.S., Pekov, I.V., Schäfer, Ch., Vigasina, M.F., and Van, K.V., Laachite $(\mathrm{Ca}, \mathrm{Mn})_{2} \mathrm{Zr}_{2} \mathrm{Nb}_{2} \mathrm{TiFeO}_{14}$, a new zirconoliterelated mineral from the Eifel volcanic region, Germany, Eur. J. Mineral., 2014, vol. 26, pp. 103-111.

CrysAlisPro, Agilent Technologies, version 1.171.36.20 (ed. 27-06-2012). 
Deer, W.A., Howie, R.A., and Zussman, J., Rock-Forming Minerals. Vol 2A: Single-Chain Silicates, London: Longman, 1978.

Grangeon, S., Claret, F., Lerouge, C., Warmont, F., Sato, T., Anraku, S., Numako, C., Linard Y., and Lan-son, B., On the nature of structural disorder in calcium silicate hydrates with a calcium/silicon ratio similar to tobermorite, Cem. Concr. Res., 2013, vol. 52., pp. 31-37.

Harada, K., Sekino, H., Nagashima, K., Watanabe,T., and Momoi H., High-iron bustamite and fluorapatite from the Broken Hill mine, New South Wales, Australia, Mineral. Mag., 1974, vol. 39, pp. 601-604.

Mason, B., Compositional limits of wollastonite and bustamite., Am. Mineral., 1975, vol. 60, pp. 209-212.

Mineraly. Sparovochnik (Minerals. Reference Book) Chukhrov, F.V. and Smolyaninova, N.N., Eds. Moscow: Nauka, 1981, vol. III, pt. 2.

Ohashi, Y. and Finger, L.W., The role of octahedral cations in pyroxenoid crystal chemistry. I. Bustamite, wollastonite, and pectolite-schizolite-serandite series, Am. Mineral., 1978, vol. 63, pp. 274-288.
Palatinus, L. and Chapuis G. SUPERFLIP - a computer program for the solution of crystal structures by charge flipping in arbitrary dimensions, J. Appl. Cryst., 2007, vol. 40, pp. 786-790.

Peacor, D.R. and Buerger, M.J., Determination and refinement of the crystal structure of bustamite, $\mathrm{CaMnSi}_{2} \mathrm{O}_{6}, Z$. Kristallogr., 1962, vol. 117, pp. 331-343.

Peacor, D. R. and Prewitt, M.J., Comparison of the crystal structures of bustamite and wollastonite, Am. Mineral., 1963, vol. 48. pp. 588-596.

Petricek, V., Dužek, M., and Palatinus, L., Jana 2006. Structure Determination Software Programs, Praha, Institute of Physics, 2006.

Shimazaki, H. and Yamanaka, T., Iron-wollastonite from skarns and its stability relation in the $\mathrm{CaSiO}_{3}-\mathrm{CaFeSi}_{2} \mathrm{O}_{6}$ join, Geochem. J., 1973, vol. 7, pp. 67-79.

Yamanaka, T., Sadanaga, R., Takeuchi, Y., Structural variation in the ferrobustamite solid solution, Am. Mineral., 1977, vol. 62, pp. 1216-1224.

Translated by I. Baksheev 